\title{
ANTIPHOSPHOLIPID ANTIBODIES IN 57 CHILDREN AND ADOLESCENTS WITH SYSTEMIC LUPUS ERYTHEMATOSUS
}

\author{
Lúcia Maria de Arruda Campos, Maria Helena B. Kiss, Élbio A. D’Amico and \\ Clóvis Artur Almeida Silva
}

CAMPOS LMA et al. - Antiphospholipid antibodies in 57 children and adolescents with systemic lupus erythematosus. Rev.

Hosp. Clín. Fac. Med. S. Paulo 58(3):157-162, 2003.

OBJECTIVE: To investigate the frequencies and behavior of antiphospholipid antibodies in 57 children and adolescents with systemic lupus erythematosus.

METHODS: Anticardiolipin antibodies were investigated by ELISA and lupus anticoagulant antibodies by the international tests recommended. The antiphospholipid antibodies analyses were performed in frozen samples (mean of 5.3 samples per patient obtained during a mean follow-up period of 3 years and 7 months) and on blood samples collected between January 1997 and November 1998 (mean of 2.5 samples per patient during a 2-year follow-up period).

RESULTS: The frequencies of antiphospholipid antibodies (anticardiolipin and lupus anticoagulant) were similar in the samples collected prospectively and in the frozen samples (retrospective study): $63.2 \%$ and $75.4 \%$ respectively. Positivity for these antibodies fluctuated during the follow-up period and was not associated with any clinical or laboratory parameters of lupus erythematosus, including autoantibodies and also including disease activity and/or severity scores.

CONCLUSIONS: The frequencies of antiphospholipid antibodies in children and adolescents with lupus erythematosus were similar to those observed in adults. The positivity fluctuated during the follow-up and was not correlated with clinical and/or laboratory disease parameters.

DESCRIPTORS: Antiphospholipid antibodies. Children. Systemic lupus erythematosus.

The antiphospholipid (aPL) antibodies constitute a heterogeneous family of autoantibodies that react against antigenic epitopes present in negatively charged phospholipids, in complex phospholipid-plasmatic proteins, or even directly in plasmatic proteins ${ }^{1}$.

These antibodies are not always pathogenic. They are present in several situations, such as infections, tumors, use of drugs, and even in $3 \%$ to $4 \%$ of normal individuals, without being related to thrombotic phenomena $^{2,3}$. The aPL antibodies can also be detected in several autoimmune diseases, for example, systemic lupus erythematosus (SLE), Sjögren's syndrome, systemic sclerosis, eosinophilic fasciitis, vasculitis, Behçet's disease, Lyme disease, sarcoidosis and rheumatoid arthritis ${ }^{4}$.

Antiphospholipid syndrome (APS) is an entity characterized by the presence of arterial or venous thrombotic phenomena or by the occurrence of reccurented abortions associated with the presence of antiphospholipid (aPL) antibodies, positive on at least 2 oc-

From the Paediatric Rheumatology Unit of the Children's Institute and Haematology Unit, Hospital das Clínicas, Faculty of Medicine, University of São Paulo - São Paulo/SP, Brazil.

Received for publication on September 27, 2002. casions $^{5}$. In medical practice, only the anticardiolipin antibodies (aCL) and lupus anticoagulant (LAC) antibodies are available for detecting the aPL antibodies.

Only a few studies have evaluated the frequency and behavior of the aPL antibodies and the APS in children with SLE. The positivity of the aPL antibodies varies from $19 \%$ to $87 \%$ (mean 56\%) for the aCL antibodies and from $11 \%$ to $62 \%$ (mean $31 \%$ ) for LAC antibodies. Antiphospholipid syndrome is present in $9 \%$ to $24 \%$ of the cases $^{6}$. Clinical manifestations relative to the presence of aPL antibodies are similar in children and adults, with a prevalence of venous thrombosis. 
This study was designed to evaluate the frequency and behavior of aPL antibodies in Brazilian children and adolescents with SLE.

\section{PATIENTS AND METHODS}

A total of 57 children and adolescents with SLE (according to the criteria revised in 1982 by the American College of Rheumatology $y^{7}$ ) were evaluated from January 1997 to November 1998. The 57 children and adolescents were selected from a sample of 109 patients with SLE that were diagnosed at this service. The inclusion criteria were the diagnosis of SLE and correct follow-up (appointments, laboratory tests, and treatment) between January 1997 and November 1998. Patients with more than 1 hospitalization due to severe infectious events were excluded.

The patients presented a mean age of 14.7 years (range, 6 to 22 years) and a female to male ratio of 5.3 to 1 . The mean age of disease onset was 10.2 years (range, 1 to 16 years).

The determination of the presence of aPL antibodies was performed on frozen samples obtained during a mean follow-up period of 3 years, 7 months (mean of 5.3 samples per patient, range, 1 to 10 samples), collected at patient admission, annually, and/or according to clinical indication during the course of the disease, as well as on blood samples collected prospectively (mean of 2.5 samples (range, 1 to 3 ) per patient during a 2-year follow-up period from January 1997 to November 1998).

The laboratory technique used for all samples to detect the ACL antibody was the enzyme-linked immunosorbent assay (ELISA) using the commercial kit Hemagen Anticardiolipina ${ }^{\circledR}$, with results given in international units (GPL and MPL). The values were considered positive when above 10 GPL or 10 MPL. The following international recommendations ${ }^{8}$ were used to detect the LAC antibodies in all the samples: 3 screening tests were performed (activated partial thromboplastin time - aPTT, dilute Russell's viper venom test - DRVVT and kaolin clotting time - KCT), and when indicated, the confirmatory tests (PNP (platelet neutralization procedure) of aPTT and/ or PNP of the DRVVT).

The evaluation of clinical and laboratory manifestations and the disease course was based on a retrospective analysis of the records of each patient, from admission to the end of the study in November 1998. The activity of the SLE was checked at the time of each blood sample collection, based on the erythrocyte sedimentation rate (ESR) value and the systemic lupus erythematosus disease activity index (SLEDAI).

The statistical analysis was performed using the chi-square test, Fish- er's exact test, $t$ test for 2 independent samples, Kruskal Wallis test, and Cochran's Q test, with statistical significance established with a probability of $95 \%$. Spearman's coefficient of correlation was used for the correlation analysis.

\section{RESULTS}

Of the 57 children and adolescents with SLE studied, aPL antibodies were positive in $63.2 \%$ and $75.4 \%$ of the cases, respectively, in the samples collected between January 1997 and November 1998 and in frozen samples (retrospective analysis) (Tables 1 and 2 ). The number of samples collected per patient varied from 1 to 3 (mean 2.5 samples per patient) in the 2-year study and 1 to 10 (mean 5.3) in the retrospective study.

Both analyses yielded similar results regarding positivity of the aPL antibodies and their isotypes. Positivity for aPL antibodies varied during the study, being increased when only 1 sample was necessary to define this positivity, as compared to the necessity of 2 or more samples (Tables 1 and 2).

To relate the presence of aPL antibodies, demographic data, and clinical and laboratory manifestations, the frequencies of aPL antibodies found in the retrospective study (frozen samples) were used.

There was no significant difference

Table 1 - Frequency of antiphospholipid antibodies (aPL) in 57 children and adolescents with systemic lupus erythematosus in the samples collected between January 1997 and November 1998.

\begin{tabular}{|c|c|c|c|c|c|}
\hline & \multicolumn{3}{|c|}{ anticardiolipin (aCL) } & \multirow[b]{2}{*}{$\begin{array}{l}\mathrm{LAC} \\
\mathrm{n} / \mathrm{N}(\%)\end{array}$} & \multirow[b]{2}{*}{$\begin{array}{l}\mathrm{aPL} \\
\mathrm{n}(\%)\end{array}$} \\
\hline & $\begin{array}{l}\operatorname{IgG} \\
\mathrm{n}(\%)\end{array}$ & $\begin{array}{l}\mathrm{IgM} \\
\mathrm{n}(\%)\end{array}$ & $\begin{array}{l}\text { IgG and/or IgM } \\
\mathrm{n}(\%)\end{array}$ & & \\
\hline $1^{\text {st }}$ sample $(n=57)$ & $6(10.5)$ & $18(31.6)$ & $20(35.1)$ & $7 / 52(13.5)$ & $23(40.3)$ \\
\hline $2^{\text {nd }}$ sample $(n=48)$ & $5(10.4)$ & $19(39.6)$ & $19(39.6)$ & $7 / 47(14.9)$ & $24(50.0)$ \\
\hline $3^{\text {rd }}$ sample $(n=36)$ & $1(2.8)$ & $13(36.1)$ & $13(36.1)$ & $2 / 21(9.5)$ & $13(36.1)$ \\
\hline+ in at least one sample $(n=57)$ & $9(15.8)$ & $29(50.9)$ & $30(52.6)$ & $12 / 55(21.8)$ & $36(63.2)$ \\
\hline+ in two or more samples $(n=48)$ & $3(6.2)$ & $15(31.2)$ & $16(33.3)$ & $3 / 45(6.7)$ & $17(35.4)$ \\
\hline
\end{tabular}

$+=$ positive for antibody; LAC = lupus anticoagulant antibody; $\mathrm{n} / \mathrm{N}=$ number of positive samples / total number of samples. 
Table 2 - Frequency of antiphospholipid antibodies (aPL) in 57 children and adolescents with systemic lupus erythematosus, in at least 1 sample and in 2 or more samples, via retrospective analysis (mean follow up $=3.7$ years).

\begin{tabular}{|c|c|c|c|c|c|}
\hline & \multicolumn{3}{|c|}{ anticardiolipin (aCL) } & \multirow[b]{2}{*}{$\begin{array}{l}\mathrm{LAC} \\
\mathrm{n} / \mathrm{N}(\%)\end{array}$} & \multirow[b]{2}{*}{$\begin{array}{l}\mathrm{aPL} \\
\mathrm{n}(\%)\end{array}$} \\
\hline & $\begin{array}{l}\mathrm{IgG} \\
\mathrm{n}(\%)\end{array}$ & $\begin{array}{l}\operatorname{IgM} \\
\mathrm{n}(\%)\end{array}$ & $\begin{array}{l}\text { IgG and/or IgM } \\
\text { n }(\%)\end{array}$ & & \\
\hline+ in at least 1 sample $(n=57)$ & $29(50.9)$ & $33(57.9)$ & $40(70.2)$ & $16 / 55(29.1)$ & $43(75.4)$ \\
\hline+ in 2 or more samples $(n=54)$ & $12(22.2)$ & $20(37.0)$ & $26(48.1)$ & $7 / 47(14.9)$ & $31(57.4)$ \\
\hline
\end{tabular}

$+=$ positive for antibody; LAC $=$ lupus anticoagulant antibody; $\mathrm{n} / \mathrm{N}=$ number of positive samples / total number of samples.

between the group of patients with positive aPL $(n=43)$ and the group of patients with negative aPL $(\mathrm{n}=14)$ in terms of age, age at presentation, follow-up, gender or race (Table 3). The number of samples was higher in the group that was positive for aPL $(P=$ 0.031 ).

There was no association between the presence of the aPL antibodies and the involvement of any organs/systems evaluated (Table 4), except in relation to impairment of the reticuloendothelial system, where a higher frequency of hepatomegaly was observed in the children and adolescents with SLE and positive aPL antibodies $(P=0.021)$.

Regarding the disease activity, no linear correlation was found between the titers of IgG or IgM aCL antibodies and the activity of SLE, when considering the mean titers of aCL antibodies and mean values of ESR and SLEDAI throughout the follow-up period. A weak correlation $(\mathrm{r}=0.38)$, albeit significant $(P=0.009)$, was observed between the IgM aCL antibody and the ESR levels when considering only an isolated sample (the first) of the 57 patients. Regarding the course of the disease, remission was found more frequently $(P=0.035)$ in the group negative for aPL antibodies when compared to the group presenting aPL antibodies $(46.1 \%$ and $16.3 \%$, respectively).

Antiphospholipid syndrome was diagnosed in 8 patients (14\%) (Table 5). All patients presented positive IgG aCL antibodies, 7 presented IgM aCL antibodies, and 6 presented LAC antibodies. Arterial events were found in 4 patients (ischemic vascular cerebral accident (IVCA) - 3, amaurosis fugax

- 2, transient ischemic attack (TIA) - 1, renal thrombosis - 1), and deep venous thrombosis (DVP) - 1. Two patients presented osteonecrosis, and transverse

Table 3 - Antiphospholipid antibodies (IgG and IgM anticardiolipin antibodies) and demographic data in 57 children and adolescents with systemic lupus erythematosus.

\begin{tabular}{lll}
\hline & $\begin{array}{l}\text { positive aPL } \\
\mathrm{n}=43\end{array}$ & $\begin{array}{l}\text { negative aPL } \\
\mathrm{n}=14\end{array}$ \\
\hline AGE (mean/median) & $15.1 / 14$ & $13.6 / 16$ \\
AGE AT PRESENTATION (mean/median) & $10.4 / 11$ & $9.6 / 10$ \\
FOLLOW-UP (mean/median) & $3.9 / 3$ & $3.2 / 3$ \\
FEMALE:MALE RATE & $36: 7$ & $12: 2$ \\
CAUCASIANS & $22(51.2 \%)$ & $4(28.6 \%)$ \\
ADMIXTURE & $16(37.2 \%)$ & $6(42.8 \%)$ \\
NUMBER OF SAMPLES (mean/median) & $5.6 / 6$ & $4.1 / 4 *$ \\
\hline
\end{tabular}

aPL $=$ antiphospholipid antibodies; $* P=0.031$

Table 4 - Antiphospholipid antibodies (IgG and IgM anticardiolipin antibodies) and organs/systems involvement in 57 children and adolescents with systemic lupus erythematosus

\begin{tabular}{lll}
\hline & $\begin{array}{l}\text { positive aPL } \\
\mathrm{n}=43 \\
\mathrm{n}(\%)\end{array}$ & $\begin{array}{l}\text { negative aPL } \\
\mathrm{n}=14 \\
\mathrm{n}(\%)\end{array}$ \\
\hline HEPATOMEGALY & $18(41.8)$ & $1(7.1)^{*}$ \\
LIVEDO RETICULARIS & $11(25.6)$ & $2(14.3)$ \\
OSTEONECROSIS & $2(4.6)$ & $0(0)$ \\
VALVULITIS & $10(23.2)$ & $2(14.3)$ \\
HEMOLYTIC ANEMIA & $17(39.5)$ & $6(42.8)$ \\
THROMBOCYTOPENIA & $12(27.9)$ & $3(21.4)$ \\
HEADACHES & $12(27.9)$ & $6(42.8)$ \\
CHOREA & $2(4.6)$ & $0(0)$ \\
STROKES & $3(6.9)$ & $4(28.6)$ \\
PSYCHOSIS & $3(6.9)$ & $0(0)$ \\
VASCULAR CEREBRAL ACCIDENT & $3(6.9)$ & $2(14.3)$ \\
TRANSIENT ISCHEMIC ATTACKS & $1(2.3)$ & $1(7.1)$ \\
AMAUROSIS FUGAX & $2(4.6)$ & $0(0)$ \\
TRANSVERSE MYELITIS & $1(2.3)$ & $0(0)$ \\
COAGULATION ABNORMALITIES & $9(20.9)$ & $0(0)$ \\
BFP-STS & $1(2.3)$ & $0(0)$
\end{tabular}

$\mathrm{aPL}=$ antiphospholipid antibodies; BFP-STS = biologic false positive serological test for syphilis; $* P=0.021$ 
Table 5 - Characteristics of antiphospholipid syndrome (APS) in 8 patients with systemic lupus erythematosus (SLE).

\begin{tabular}{|c|c|c|c|}
\hline CASE & Thrombotic manifestations & Other manifestations related to APS & $\begin{array}{l}\text { Interval until the } \\
\text { diagnosis of APS, after } \\
\text { the diagnosis of SLE }\end{array}$ \\
\hline $\mathbf{1}$ & IVCA & hemolytic anemia, thrombocytopenia, livedo reticularis & $3 \mathrm{yr} 3 \mathrm{~m}$ \\
\hline 8 & $\operatorname{DVT}(2 \mathrm{x})$ & hemolytic anemia, thrombocytopenia & $3 \mathrm{yr} 2 \mathrm{~m}$ \\
\hline 9 & Renal thrombosis & hemolytic anemia, thrombocytopenia, valvulitis & $7 \mathrm{~m}$ \\
\hline 19 & Osteonecrosis & thrombocytopenia, migraine & $5 \mathrm{yr} 11 \mathrm{~m}$ \\
\hline 22 & Amaurosis fugax, TIA, IVCA $(2 x)$ & hemolytic anemia, thrombocytopenia, behavioral disturbances & $6 \mathrm{~m}$ \\
\hline 24 & Osteonecrosis & hemolytic anemia, thrombocytopenia, migraine & 3 yr $7 \mathrm{~m}$ \\
\hline 26 & Amaurosis fugax, IVCA & hemolytic anemia, thrombocytopenia, migraine & $2 \mathrm{yr} 11 \mathrm{~m}$ \\
\hline 49 & Transverse myelitis & - & $3 \mathrm{yr} 10 \mathrm{~m}$ \\
\hline
\end{tabular}

IVCA = ischemic vascular cerebral accident; TIA = transient ischemic attack; DVT = deep venous thrombosis

myelitis was found in the last one. Three patients presented more than 1 event (mean interval of 13 months between them). Hemolytic anemia and thrombocytopenia were found in 6 and 7 patients, respectively. Other manifestations related to APS found in these patients included headaches (3), valvulitis (1), behavioral disturbances (1) and livedo reticularis (1). The interval between SLE and APS diagnosis was 3 years (ranging from 6 months and 5 years, 11 months).

\section{DISCUSSION}

In this study, the frequencies of aPL antibodies presented a very well-defined behavior. The number of individuals positive for aPL antibodies on at least 1 occasion was larger than the number of individuals positive on 2 or more occasions. This fact was observed both in the samples collected between January 1997 and November 1998 (63.2\% and $35.4 \%$, respectively) and in the frozen samples (retrospective study) (75.4\% and $57.4 \%$, respectively) for aCL antibodies and LAC antibodies, which suggest a cyclical behavior of these autoantibodies.

Several works have verified that the positivity of the aPL antibodies is linked to the time of follow-up and the number of times that it is tested $d^{9 ; 10 ; 11}$. PÉREZ-VÁZQUEZ et al. ${ }^{10}$ demon- strated that when they extended the follow-up of a group of 667 lupus patients from 7.5 months to 3.1 years, the frequency of aPL antibodies increased from $52 \%$ to $66 \%$, with a consequent increase in the number of cases in which it was possible to diagnose APS (from $10 \%$ to $15 \%$ ).

Regarding the isotypes, the aCL antibody was detected more frequently than the LAC antibody $52.6 \%$ and $21.8 \%$, respectively, in the samples collected in the 2-year study and $70.2 \%$ and $29.1 \%$ in the retrospective study - frozen samples). This finding is in agreement with data reported in literature, where the positivity for aPL antibodies among lupus children varies from $19 \%$ to $87 \%$ (mean $56 \%$ ) for the aCL antibody and from $11 \%$ to $62 \%$ (mean $31 \%$ ) for LAC antibodies ${ }^{6}$.

The IgM aCL isotype was found more frequently than the IgG aCL isotype in both analyses. This difference was maintained when we selected the patients that were positive on 2 or more occasions. In the literature, the $\mathrm{IgG}$ isotype is reported to be the most common in adults and children with lupus $^{12}$.The clinical manifestations related to the presence of aPL antibodies in children are similar to those found in adults, in agreement with the literature review performed by Ravelli \& Martini in $1997^{6}$.

In this study, the presence of the aPL antibodies was not correlated with a specific clinical or laboratory profile among the children and adolescents studied. Hepatomegaly was the only manifestation that was statistically more frequent in the group with positive aPL antibodies. In the literature, there are reports of patients with APS, hepatomegaly, and an increase in the hepatic enzymes, which is attributed to hepatic microthrombosis without any relationship to infections, drugs, congestion, and degenerative or metabolic causes ${ }^{13}$. In this study, the children that presented hepatomegaly associated with the presence of aPL antibodies $(n=18)$ did not present any other clinical or laboratory manifestations of hepatic abnormality. All the patients, except 3, presented other signs of involvement of the reticuloendothelial system, such as adenomegaly $(\mathrm{n}=14)$ and/or splenomegaly $(\mathrm{n}=6)$.

Other manifestations usually reported in the literature in association with the aPL antibodies, such as livedo reticularis, osteonecrosis, valvulitis, hemolytic anemia, and thrombocytopenia, were also not found frequently in this study. Even involvement of the central nervous system (with manifestations such as headaches, strokes, transient ischemic attacks, amaurosis fugax, psychosis, chorea, and transverse myelitis), which in the studies by RAVELLI et al. ${ }^{12}$ and SHERGY et al. ${ }^{14}$ was reported to be associated with the presence of aPL antibodies, was 
not observed in the patients of this study. Coagulation abnormalities, characterized by prolongation of the prothrombin time and/or activated partial thromboplastin time, were only found in the patients with positive aPL antibodies $(20.9 \%)$ and in none of the patients with negative aPL antibodies. The low frequency of these abnormalities indicates the low sensitivity of these parameters as screening methods for the detection of aPL antibodies, as has already been observed by PETRI ${ }^{2}$. The same is true in relation to the biologic false-positive serological test for syphilis (BFP-STS) that was found in just 1 patient with positive aPL antibodies.

In the studies by RAVELLI et al. ${ }^{12}$ and SHERGY et al. ${ }^{14}$ in children with SLE, it can be seen that the positivity of the aPL antibodies fluctuated during the follow-up. RAVELLI et al. ${ }^{12} \mathrm{dem}-$ onstrated a relationship between the titers of the aCL antibody and disease activity when the ESR, the reduction in the $\mathrm{C} 3$ fraction of the complement, and Systemic Lupus Activity Measure (SLAM) were analyzed, but this correlation was not maintained when SLEDAI and anti-DNA antibody were used as parameters of disease activity.

In this study, it was observed that fewer patients with positive aPL antibodies tended to experience disease remission, when compared to patients with negative aPL antibodies $(P=$ $0.035)$. It is possible that patients with a remittent disease course produce fewer autoantibodies and consequently present a lower frequency of aPL antibodies.

This study, and its similarity to others in the literature, presents some interesting aspects.

The behavior of the aPL antibodies was cyclical in terms of positivity, with a higher frequency in the longer periods of follow-up and/or larger number of samples collected. There was no clear relationship of the occurrence of aPL antibodies with disease activity, severity, or clinical and laboratory manifestations. It is possible that their occurrence has a relationship with the etiopathic mechanism of the SLE itself (production of multiple autoantibodies) or with the appearance of neoantigens due to the process of chronic vasculitis or also due to the chronic use of corticosteroids, causing abnormalities in lipid metabolism. This second hypothesis (exposure to neoantigens) could explain the late emergence of the manifestations related to the aPL antibodies during the follow-up of patients with SLE.

There was also no correlation between the presence of aPL antibodies and specific clinical manifestations, which does not support a pathogenic role for these antibodies. It is possible that there are pathogenic aPL antibodies and nonpathogenic aPL antibodies, which would explain the high frequency of patients with SLE that have aPL antibodies and the low relative frequency of APS in these patients. In fact, various authors have suggested that the pathogenic aPL antibodies could be those dependent on the $\beta 2$ GP1 $1^{3 ; 15}$. While studying the aCL and anti- $\beta 2-G P 1$ antibodies in patients with SLE, AMENGUAL et al..$^{15}$ observed that the former were present in $70.4 \%$ of the cases with APS and in $24.5 \%$ of the patients without APS, while the anti- $\beta 2-\mathrm{GP} 1$ were present in $53.5 \%$ and $4.1 \%$, respectively. Thus, the anti- $\beta 2-G P 1$ antibody was more specific, while being less sensitive. $\mathrm{Pa}-$ tients that are positive for aCL antibodies and negative for anti- $\beta 2-\mathrm{GP} 1$ antibodies could correspond to the cases in which the aCL antibodies are independent from the $\beta 2$-GP1 and are therefore nonpathogenic, or also pathogenic, through the connection with other plasmatic proteins. Further studies with the intention of identifying the pathogenic role of the aPL antibodies and their connection with specific plasmatic proteins will be important to establish the real role of aPL antibodies in patients with SLE.

\section{RESUMO}

CAMPOS LMA e col. - Anticorpos antifosfolípides em 57 crianças e adolescentes com lúpus eritematoso sistêmico. Rev. Hosp. Clín. Fac. Med. S. Paulo 58(3):157-162, 2003.
OBJETIVO: Investigar a frequiência e o comportamento dos anticorpos antifosfolípides em 57 crianças e adolescentes com lúpus eritematoso sistêmico.

MÉTODOS: A técnica laboratorial para a pesquisa do anticorpo anticardiolipina foi ELISA e para a pesquisa do anticorpo anticoagulante lúpico foram seguidas as recomendações internacionais. A pesquisa dos anticorpos antifosfolípides foi realizada em soros 
estocados (média de 5,3 amostras por paciente durante o período de seguimento de em média 3 anos e 7 meses) e em soros coletados no período de janeiro de 1997 à novembro de 1998 (média de 2,5 amostras por paciente em um período de dois anos).

RESULTADOS: A freqüência dos anticorpos antifosfolípides (anticorpo anticardiolipina e anticoagulante lúpico) foi semelhante nos soros coletados prospectivamente e nos so- ros estocados (estudo retrospectivo): $63,2 \%$ e $75,4 \%$ respectivamente. A positividade destes anticorpos flutuou durante o seguimento e não esteve associado a nenhum parâmetro clínico e laboratorial do lúpus eritematoso sistêmico, incluindo auto-anticorpos e também atividade e/ou gravidade da doença.

CONCLUSÕES: A frequiência dos anticorpos antifosfolípides em crianças e adolescentes com lúpus eritematoso sistêmico foi semelhante à observada em adultos. A positividade dos anticorpos flutuou durante o seguimento dos pacientes e não foi evidenciada associação com parâmetros clínicos e/ ou laboratoriais da doença.

DESCRITORES: Anticorpos antifosfolípides. Crianças. Lúpus eritematoso sistêmico.

\section{REFERENCES}

1. VAARALA O - Antiphospholipid antibodies and atherosclerosis. Lupus 1996; 5: 442-447.

2. PETRI MA - Diagnosis of antiphospholipid antibodies. In: ANNUAL SCIENTIFIC MEETING OF THE AMERICAN COLLEGE OF RHEUMATOLOGY, 57 th $^{\text {t }}$ San Antonio, 1993. San Antonio, Clinical symposium, 1993. p. 3-6.

3. ORDI J, SELVA A, MONEGAL F et al. - Anticardiolipin antibodies and dependence of a serum cofactor. A mechanism of thrombosis. J Rheumatol 1993; 20: 1321-1324.

4. MACKWORTH YOUNG CG, DAVID J, LOIZOU S et al. - Primary antiphospholipid syndrome: features of patients with raised anticardiolipin antibodies and no other disorder. Ann Rheum Dis 1989; 48: 362-367.

5. ASHERSON RA, CERVERA R, PIETTE JC et al. - The antiphospholipid syndrome: history, definition, classification and differential diagnosis. In: - The antiphospholipid syndrome. Boca Raton, CRC Press, 1996. p. 3-12.

6. RAVELLI A, MARTINI A - Antiphospholipid antibody syndrome in pediatric patients. Rheum Dis Clin North Am 1997; 23: 657-676.

7. TAN EM, COHEN AS, FRIES JF et al. - The 1982 revised criteria for the classification of systemic lupus erythematosus. Arthritis Rheum 1982; 25: 1271-1277.

8. BRANDT JT, TRIPLETT DA, ALVING B et al. - Criteria for the diagnosis of lupus anticoagulants: an update on behalf of the subcommittee on lupus anticoagulant/antiphospholipid antibody of the scientific and standardisation committee of the ISTH. Thromb Haemost 1995; 74: 1185-1190.
9. PETRI M - Clinical and management aspects of the antiphospholipid syndrome. In: WALLACE DJ, HAHN BH Dubois' Lupus Erythematosus. Baltimore, Williams and Wilkins, 1997. p. 1067-1096.

10. PÉREZ-VÁZQUEZ ME, VILLA AR, DRENKARD C et al. Influence of disease duration, continued follow-up and further antiphospholipid testing on the frequency and classification category of antiphospholipid syndrome in a cohort of patients with systemic lupus erythematosus. J Rheumatol 1993; 20: 437-442.

11. PICILLO U, MIGLIARESI S, MARCIALIS MR et al. - Factors influencing the prevalence of antiphospholipid syndrome in systemic lupus erythematosus. J Rheumatol 1994; 21: 1375.

12. RAVELLI A, CAPORALI R, Di FUCCIA G et al. - Anticardiolipin antibodies in pediatric systemic lupus erythematosus. Arch Pediatr Adolesc Med 1994; 148: 398-402.

13. CERVERA R, ASHERSON RA, LIE JT - Clinicopathologic correlations of the antiphospholipid syndrome. Sem Arthritis Rheum 1995; 24: 262-272.

14. SHERGY WJ, KREDICH DW, PISETSKY DS - The relationship of anticardiolipin antibodies to disease manifestations in pediatric systemic lupus erythematosus. J Rheumatol 1988; 15: $1389-1394$.

15. AMENGUAL O, ATSUMI T, KHAMASHTA MA et al. Specificity of ELISA for antibody to beta 2-glycoprotein I in patients with antiphospholipid syndrome. Br J Rheumatol 1996; 35: 1239-1243. 